\title{
(5)
}

AL-DZIKRA

Jurnal Studi Ilmu Al-Qur'an Dan Al-Hadits

http://ejournal.radenintan.ac.id/index.php/al-dzikra

Volume 13, No. 2, Desember Tahun 2019, Halaman 171 - 194

DOI://dx.doi.org/10.24042/al-dzikra.v13i2.4164

\section{METODE KONTEKSTUAL PENAFSIRAN AL-QUR'AN PERSPEKTIF FAZLUR RAHMAN}

\begin{tabular}{c}
\hline Rudy Irawan \\
UIN Raden Intan Lampung \\
rudyirawan@radenintan.ac.id
\end{tabular}

\section{Abstract}

Rahman is a contemporary Islamic thinker who intensely studies the Qur'an. According to him, the Qur'an appears in the historical horizon and is faced with a socio-historical background, the most appropriate question to get the Qur'an is historical approach. Rahman uses Double Movements's method in his interpretation, which is a historical investigation that encompasses the text in the past to get its moral ideal which will be contextualized in contemporary society. This method or strategy is its protector and sword. On one hand this method proves how revelation has launched history. On the other hand, he will use the Qur'an as a normative standard to negate local traditions as well as religious practice values that involve norms derived from the Qur'an and sunnah. This study uses descriptiveanalytical methods to discuss and further analyze the contextual methods offered by Rahman. The conclusion that can be drawn from this approach is an approach to the Koran by undertsanding its historical situation, both before and during the revelation, then draw the moral-ideal from that revelation, and project it in the present context. In projecting the ideal morals into the 
present context, the Mufassir must direct his attention to the goal of the Qur'an (moral ideal) as a unified whole, so that it will bring up for a concrete world view (weltanschaung). In essence, the contextualization of the ideal morals will result in the formulation of the ethics of the Qur'an that is able to support and develop the integrity of individuals and collectives in contemporary society.

\section{Abstrak}

Rahman merupakan pemikir Islam kontemporer yang intens mengkaji al-Qur'an. Menurutnya, al-Qur'an muncul dalam horizon sejarah dan berhadapan dengan latar belakang sosiohistoris, maka pendekatan yang paling tepat untuk memahami al-Qur'an adalah kesejarahan (historical approach). Metode yang digunakan dalam penafsirannya adalah Double Movement, yaitu investigasi sejarah yang melingkupi teks pada lampau untuk mengambil ideal moralnya yang akan dikontekstualisasikan dalam masyarakat kontemporer. Metode ataupun strategi ini merupakan pelindung dan pedangnya. Di satu sisi metode tersebut menunjukkan bagaimana wahyu telah membuka sejarah. Di sisi lain, ia akan menggunakan al-Qur'an sebagai standar normatif untuk meniadakan tradisi-tradisi lokal juga nilai-nilai praktik agama yang mengganggu norma-norma yang diperoleh dari al-Qur'an dan sunnah. Kajian ini menggunakan metode deskriptif-analitis untuk mengeksplorasi dan menganalisa lebih lanjut metode kontekstual yang ditawarkan Rahman. Kesimpulan yang bisa diambil dari pendekatan yang dimaksud adalah suatu pendekatan terhadap al-Qur'an dengan memahami situasi kesejarahan, baik sebelum maupun dimasa pewahyuan, untuk kemudian menarik ideal-moral dari wahyu tersebut, dan memproyeksikannya dalam konteks kekinian. Dalam memproyeksikan ideal moral terhadap konteks kekinian, mufassir harus mengarahkan perhatianya pada tujuan al-Qur'an (ideal-moral) sebagai suatu keseluruhan yang utuh, sehingga akan memunculkan suatu pandangan dunia (weltanschaung) yang konkret. Secara garis besar, kontekstualisasi atas ideal moral tersebut akan menghasilkan suatu rumusan etika alQur'an yang mampu melindungi dan mengembangkan integritas para individu dan kolektif dalam masyarakat kontemporer.

Kata Kunci: Fazlur Rahman, Kontemporer, Kontekstual, Metode Penafsiran 


\section{A. Pendahuluan}

Al-Qur'an bagi insan bertaqwa merupakan pedoman yang harus diyakini tanpa ada keraguan di dalamnya dan code (undangundang) kehidupan yang lengkap dan komprehensif bagi ras manusia. ${ }^{1}$ Di dalamnya memuat berbagai macam informasi tentang ilmu pengetahuan yang bersifat dasar sehingga butuh analisa, telaah, interpretasi dan penafsiran, sehingga orisinalitas teksnya menjadi lebih nyata ketika bertemu dengan konteks yang sesungguhnya. ${ }^{2}$

Banyaknya persoalan-persoalan kemanusiaan yang tanpa henti mengharuskan pula adanya kebutuhan bagi al-Qur'an memberikan solusi yang bersifat kontekstualitas. Dalam kondisi seperti ini, menurut Hasbi kehadiran tafsir al-Qur'an merupakan keniscayaan. Tanpa mempelajari tafsir, seseorang sangat mustahil melakukan kebaikan dan amal saleh sesuai dengan wahyu Allah swt. $^{3}$ Dalam menafsirkan ayat-ayat Allah swt. dibutuhkan persyaratan yang ketat dari berbagai disiplin ilmu termasuk didalamnya penguasaan ilmu alat dan metodologi penafsiran, tanpa penguasaan metodologi penafsiran, maka seseorang akan mengalami kesulitan dalam menafsirkan al-Qur'an.

Dalam menafsirkan al-Qur'an, di samping menguasai dengan baik bahasa Arab dan metodologi penafsiran maka hal yang sangat penting untuk dimiliki seorang penafsir al-Qur'an ialah pengetahuan tentang kondisi keadaan penduduk saat wahyu diturunkan, agar penafsiran terhadap teks-teks al-Qur'an menjadi relevan dengan konteksnya. Hermeneutika al-Qur'an (tafsiran terhadap wahyu) dan sejarah (konteks Sosial) merupakan usulan yang ditawarkan Fazlur Rahman dalam menafsirkan al-Qur'an. Metode ataupun strategi ini juga merupakan pelindung dan pedangnya. Di satu sisi metode itu menunjukkan bagaimana wahyu telah membuka sejarah. Di sisi lain, ia akan menggunakan

${ }^{1}$ Fazlur Rahman, Mayor Themes of the Qur'an, (Chicago: Bibliotheca Islamica, 1980), N.K. Singh dan A.R. Aqwan(ed), Ensyclopedia of The Holy Qur'an, vol.1, (Delhi: Global Vision Publishing House, 2000, cet.1), hlm, VII

${ }^{2}$ Umar Shihab, Kontekstualitas Al-Qur'an Kajian Tematik atas Ayatayat Hukum Dalam Al-Qur'an, (Jakarta: Pena Madani,2005), hlm. xx

${ }^{3}$ Hasbi As-Shiddiqie, Ilmu-ilmu Al-Qur'an: Ilmu-ilmu Pokok Dalam Menafsirkan Al-Qur'an, (Semarang: Pustaka Rizki Putra, 2002), hlm. 212 
al-Qur'an sebagai standar normatif untuk meniadakan tradisitradisi lokal juga nilai-nilai praktik agama yang mengganggu norma-norma yang diperoleh dari al-Qur'an dan sunnah. Menurutnya praktik-praktik yang tidak memajukan visi masyarakat Islam menjadi penghambat kemajuan manusia.

Hermeneutika kesentralan al-Qur'an Fazlur Rahman didasari pada dua pilar, pertama: teori kenabian dan hakikat wahyu dan kedua pemahaman sejarah. Kedua komponen itu merupakan hermeneutika umum Fazlur Rahman terhadap alQur'an. Bagi pemikir-pemikir modern seperti Fazlur Rahman sangat penting mengartikan wahyu dalam term (istilah) sejarah. Jika sejarah berpengaruh dalam memahami wahyu yang transenden, maka penting untuk menyelidiki keberadaan wahyu dengan dunia. Dengan kata lain Fazlur Rahman berusaha memberi teori wahyu yang kompleks, universal, yang menghubungkan alasan-alasan filosofis dan psikologis dengan sejarah sosiologi dan antropologi. Gagasan wahyu yang kompleks ini menjadi latar belakang dari teori penafsiran al-Qur'annya, yang disebut dengan teori double movements (pergerakan ganda).

Pergerakan pertama double movements ini ialah mempelajari konteks sosial - moral dari umat Nabi. Investigasi tersebut kemudian harus menghasilkan narasi al-Qur'an yang koheren terhadap prinsip-prinsip dan nilai-nilai yang umum dan sistematis yang mendasari perintah-perintah normatif yang bermacam-macam. Di sini konsep-konsep dari sebab turunnya wahyu (asbabun nuzul) dan nasakh (penghapusan), disamping teknik-teknik penafsiran lain yang telah diketahui, membuahkan hasil. Pergerakan kedua yaitu mencoba menggunakan nilai-nilai dan prinsip-prinsip yang umum dan sistematis itu ke dalam konteks pembaca al-Qur'an kontemporer, yakni penerapan nilainilai historis yang didapatkan kembali saat ini memerlukan analisa yang sangat cermat.

Bahkan, Fazlur Rahman menyatakan bahwa pendekatan sejarah semacam ini sangat mudah difahami dan diterima, lebih berlaku adil terhadap respons intelektual dan realitas sosial. ${ }^{4}$ Dalam hal ini tentunya perlu dikaji lebih lanjut untuk melihat dan

4 Fazlur Rahman, Metode dan Aternatif Neomodernisme Islam, Terjemahan Taufiq Adnan Amal, (Bandung: Mizan, 1987), hlm. 21 
mengetahui bagaimana sebenarnya penafsiran yang ditawarkan oleh Fazlur Rahman tersebut, terutama metode kontekstual dalam penafsiran al-Qur'an.

\section{B. Kontekstualisasi Penafsiran Al-Qur'an}

Dari segi bahasa metode berarti cara yang digunakan, cara yang dilakukan, cara memperoleh, cara menentukan, dan sebagainya. ${ }^{5}$ Kontekstual diartikan sebagai hubungan antara bahasa, ujaran, teks, wacana dengan lingkungan fisik dan sosial. ${ }^{6}$ Sedangkan istilah tafsir, secara harfiah berasal dari bahasa Arab dan merupakan bentuk masdar dari fassara serta terdiri dari huruf fa, sin dan ra yang berarti keadaan jelas (nyata dan terang dan memberikan penjelasan). ${ }^{7}$

Ahmad Al-Syirbashi memaparkan ada dua makna tafsir dikalangan ulama, yakni :(1) keterangan atau penjelasan sesuatu yang tidak jelas dalam al-Qur'an yang dapat menyampaikan pengertian yang dikehendaki, (2) merupakan bagian dari ilmu Badi' yaitu salah satu cabang ilmu sastra Arab yang mengutamakan keindahan makna dalam menyusun kalimat. ${ }^{8}$

Istilah tafsir juga dapat dilihat pada surat al-Furqan (25): 33, yang berbunyi:

$$
\text { وَلا يَأْتُونَكَ بِمَثَلِ إِلا جِنْنَاكَ بِالْحَقِّ وَأَحْسَنَ تَفْسِيرًا }
$$

'Tidaklah orang-orang kafir itu datang kepadamu (membawa) sesuatu yang ganjil, melainkan Kami datangkan kepadamu suatu yang benar dan yang paling baik penjelasannya".

Tentang definisi tafsir sendiri masih ada perbedaan pendapat dikalangan mufasir apakah masuk ranah pengetahuan ataukah sesuatu yang menjadi tujuan. Metode kontekstual berarti cara yang digunakan untuk memperoleh sesuatu dengan menghubungkan bahasa, ujaran, wacana, teks dengan kondisi

${ }^{5}$ M. Dahlan. Y. Al-Barry, L.Lya Sofyan Yacub, Kamus Induk Istilah Ilmiah Seri Intelektual, Surabaya : Target Press, 2003, hlm. 504

${ }^{6}$ M. Dahlan. Y.Al-Barry, L.Lya Sofyan Yacub, Kamus Induk Istilah Ilmiah Seri Intelektual, hlm. 415-416

${ }^{7}$ Abi al-Hasyan Ahmad Ibn Faris ibn Zakariya, Maqayis al-lughah, juz IV, (Mesir: Mustafa al-Babi al-Halai, 1970), hlm. 504

8 Ahmad al-Syirbasyi, Sejarah Tafsir al-Qur'an, terj. Tim Pustaka Firdaus, (T,t,p: Pustaka Firdaus 1994), hlm. 5 
lingkungan fisik dan sosial bahasa tersebut. Dalam hal ini bahasa, ujaran dan wacana yang dimaksud adalah teks ataupun bahasa alQur'an. Sedangkan lingkungan fisik dan lingkungan sosialnya dalam kaitannya dengan penafsiran al-Qur'an berarti keadaaan ataupun kondisi fisik (Rasulullah dan masyarakat Arab) sebelum menerima wahyu tersebut dan keadaan masyarakat Arab waktu wahyu tersebut diturunkan. Kondisi fisik dan kondisi sosial yang mengitari bahasa al-Qur'an inilah disebut historis (kesejarahan).

Dengan demikian metode kontekstual dalam penafsiran alQur'an adalah cara ataupun pendekatan yang digunakan untuk memahami kandungan al-Qur'an dengan menggunakan cara ataupun pendekatan kesejarahan (historical approach). Pendekatan kesejarahan (historical approach) yang dimaksud adalah pendekatan terhadap al-Qur'an dengan memahami situasi kesejarahan atau konteks historisitas, baik sebelum atau dimasa pewahyuan untuk kemudian ditarik ideal moral dari wahyu tersebut dan memproyeksikannya dalam konteks kekinian. ${ }^{9}$

\section{Sekilas Tentang Biografi Fazlur Rahman}

Rahman terlahir diwilayah sebelum terpecahnya Hindustan yang saat ini bagian dari Pakistan yakni Hazara diantara keluarga besar Malak pada tanggal 21 September 1919. Ia wafat pada tanggal 26 Juli 1988, di Chicago, Illinois. Di abad ke 19, umat Islam India-Pakistan dapat dikatakan masih hidup dengan tradisi kebesaran dan kemegahan di masa lalu. Tetapi, pada abad kedua puluh, sebagian dari mereka telah bangkit dengan visi yang campur aduk antara kebesaran masa lalu yang telah hilang dan impian kebesaran yang akan datang. ${ }^{10}$

Dalam situasi inilah Fazlur Rahman, tokoh kontroversial asal daerah barat laut Pakistan ini lahir, saat nama anak benua India- Pakistan belum terpilah menjadi dua Negara yang merdeka. Sebagaimana keluarga-keluarga muslim lainnya, dia pun berasal dari keluarga muslim yang amat religius, yang mempraktekkan

${ }^{9}$ Akhmad Arif Junaidi, Pembaruan Metodologi Tafsir Al-Qur'an, Cet. Ke-1, (Semarang: Gunung Jati, 2000), hlm. 60

${ }^{10}$ Metcalf, Barbara Daly, Islamic Revival in British India: Doeband, 1860-1900, (Princeton: Princeton University Press, 1982), hlm. 82-83 
ibadah-ibadah ke-Islaman dengan taat tanpa meninggalkannya sekalipun. ${ }^{11}$

Fazlur Rahman mengakui bahwa kedua orang tuanya, penganut mazhab Hanafi, sangat berpengaruh dalam membentuk watak dan keyakinan-keyakinan awal religiusnya. Dari sang ibu, Rahman banyak mendapatkan pengajaran tentang nilai-nilai kebenaran, kasih sayang, kesetiaan dan cinta di atas segalanya. Sedangkan sang Ayah justru memandang modernitas sebagai tantangan-tantangan maupun kesempatan-kesempatan, suatu pandangan yang juga dipegang oleh Rahman hingga akhir hayatnya.

Disamping mendapatkan pendidikan agama dari ayahnya, Fazlur Rahman juga memasuki sebuah sekolah modern di Lahore yang merupakan tempat tinggal leluhurnya. Setelah menyelesaikan pendidikan tingkat menengahnya di kota tersebut, Rahman memasuki Departemen Ketimuran Universitas Punjab dan meraih gelar master dalam Sastra Arab pada 1942. Ketika di tengah melanjutkan studi S3-nya di Universitas tersebut, alMaududi pernah berusaha merekrutnya untuk masuk menjadi anggota Jama'ah Islami dengan meninggalkan studinya. Rahman menolak tawaran tersebut karena memang ingin sepenuhnya terjun di kancah intelektual. ${ }^{12}$

Pada tahun 1946 Rahman, yang karena menyadari rendahnya pendidikan keislaman di India, akhirnya memutuskan untuk melanjutkan studi program doktornya di Oxford University, Inggris-suatu keputusan yang sangat berani untuk ukuran waktu itu. Dan di Oxford inilah Rahman mempersiapkan disertasinya tentang Psikologi Ibnu Sina di bawah pengawasan Prof. Simon Van Den Bergh. Disertasi itu merupakan terjemahan, kritikan dan komentar pada bagian dari kitab An-Najt milik filosof muslim kenamaan abad ke-7. Setelah di Oxford, ia mengajar Bahasa Persi dan filsafat Islam di Durham University dari tahun 1950-1958. Ia meninggalkan Inggris untuk menjadi Associate Professor pada

${ }^{11}$ Fazlur Rahman, An Autobiographical Note, terjemahan. Ihsan Ali Fauzi, Volume. VI, (Yogyakarta: Al-Hikmah, 1992), hlm. 598

12 Fazlur Rahman, Islam and Modernity: Transformation of an Intelectual Tradition, (Chicago: The University of Chicago Press, 1982), hlm. 117 
kajian Islam di Institude of Islamic Studies Mc.Gill University Canada di Moentreal. Di institute itulah tempat yang mempertemukan Rahman dengan WC. Smith, orientalis kenamaan yang waktu itu menjabat sebagai Direktur IIS di Universitas tersebut.

Pada awal dekade 1960-an, ketika masih berada di Mc. Gill University, Rahman dipanggil pulang ke tanah airnya, Pakistan, oleh Presiden Pakistan waktu itu, Ayyub Khan. Rahman yang nampaknya telah mulai siap terjun ke kancah pertarungan intelektual di negeri kelahirannya ini pun memenuhi panggilan tersebut. Sebagaimana diketahui bahwa kondisi Pakistan saat itu baru mulai mencari identitas keislamannya. Di situlah paling tidak ada tiga kubu yang berbeda saling bertarung dalam rangka memberikan definisi ideologis bagi Pakistan sebagai sebuah negara yang merdeka, yaitu antara kubu-tradisionalis, fundamentalis dan modernis. ${ }^{13}$

Sesampainya di Pakistan, banyak sekali aktivitas jabatan pemerintahan yang ditangani oleh Rahman, diantaranya pada 1962, Rahman ditunjuk menjadi Direktur dari lembaga yang bertugas untuk menafsirkan Islam dalam term-term rasional dan ilmiah untuk memenuhi kebutuhan-kebutuhan suatu masyarakat moderat yang progresif.

Dua tahun kemudian, Rahman juga diangkat sebagai anggota Advisory Council of Islamic Ideology (Dewan Penasehat Ideologi Islam Pemerintah Pakistan). Aktivitas Rahman di kedua lembaga yang berada di bawah naungan pemerintah Pakistan tersebut memang ibarat memegang pisau tajam. Pada satu sisi, kedua lembaga tersebut memang sangat kondusif bagi upayaupaya pengembangan pemikiran keagamaannya, namun disisi lain, keberadaannya pada dua lembaga tersebut justru menyeretnya pada kancah pertarungan intelektual yang tidak bisa disebut sehat.

Oposisi intelektual yang tidak bersahabat dari kalangan fundamentalis maupun tradisional Pakistan nampaknya telah membuat Rahman berpikir bahwa negaranya memang belum siap

13 Fazlur Rahman, Metode dan Aternatif Neomodernisme Islam, Terjemahan Taufiq Adnan Amal, hlm. 83 
menyediakan ruang kebebasan intelektual yang bertanggung jawab bagi dirinya. Maka tidak mengherankan pada 1970, Rahman memutuskan untuk hijrah ke Chicago, Amerika Serikat. Di Chicago, ia menyusun dan merumuskan pemikirannya tentang Islam, dan dari sana pulalah beberapa mahasiswa muslim dari berbagai negeri Islam belajar Islam kepadanya. ${ }^{14}$

\section{Pandangan Fazlur Rahman Tentang Al Qur'an}

Menurut Fazlur Rahman “al-Qur'an” terbagi dalam babbab atau surah-surah, yang semuanya berjumlah 114 dengan panjang yang sangat beragam. Surah Makkiyah adalah yang awal, dan termasuk surah-surah paling pendek dan makin lama surahsurah itu makin panjang. Ayat-ayat dalam surah-surah yang terdahulu diturunkan mengandung 'momen psikologis' yang dalam dan kuat luar biasa, serta memiliki sifat-sifat seperti ledakan-ledakan vulkanis yang singkat tapi kuat. Sebuah suara yang meratap dari dasar kedalaman hidup dan membentur dengan kuat pada dinding-dinding pikiran Nabi untuk membuat dirinya hadir secara nyata pada tingkat kesadaran manusia. Nada seperti ini lama kelamaan menghilang, terutama dalam periode Madinah/Madaniyah, berganti dengan gaya yang lebih tenang dan lancar berbarengan dengan kandungan hukum dalam al-Qur'an bertambah banyak, yang ditujukan untuk mengatur organisasi yang terperinci dan memberikan pengarahan kepada masyarakatNegara umat Islam yang baru lahir".

Dalam persoalan pewahyuan al-Qur'an sepertinya Fazlur Rahman berbeda pendapat dengan pandangan ortodoks Islam yang memberikan gambaran bahwa proses pewahyuan al-Qur'an kepada Nabi Muhammad secara keseluruhannya "datang melalui telinga" dan bersifat eksternal dari diri Nabi Muhammad serta memandang Jibril atau Ruhul al-Amin sebagai agen eksternal, yang seolah-olah Jibril menyampaikan wahyu al-Qur'an kepada Nabi Muhammad seperti tukang pos yang mengantarkan surat. Menurut Rahman, al-Qur'an menjelaskan bahwa Allah swt. tidak berbicara pada seorang manusia pun (yakni dengan kata-kata

14 Akhmad Arif Junaidi, Pembaruan Metodologi Tafsir Al-Qur'an, hlm. 52

${ }^{15}$ Fazlur Rahman, Islam, Cet. Ke-2, (Bandung: Pustaka, 1994), hlm. 31 
bersuara) kecuali melalui wahyu (yakni dengan inspirasi ide-kata) atau dari balik tabir, atau Ia mengutus seorang utusan (Malaikat) yang berbicara melalui wahyu sebagaimana yang difirmankan oleh Allah swt. dalam QS. Asy-Syuura: 51:

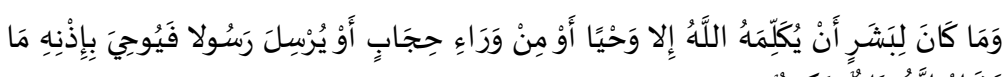

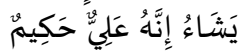

"Dan tidak mungkin bagi seorang manusiapun bahwa Allah berkata-kata dengan dia kecuali dengan perantaraan wahyu atau dibelakang tabir atau dengan mengutus seorang utusan (malaikat) lalu diwahyukan kepadanya dengan seizin-Nya apa yang Dia kehendaki. Sesungguhnya Dia Maha Tinggi lagi Maha Bijaksana”.

Atas dasar QS. asy-Syuura: 51 tersebut, Fazlur Rahman nampaknya ingin menandaskan bahwa kata-kata tersebut tidak 'didiktekan' melalui suara yang ada di luar Muhammad yang didengarnya melalui telinga. Kata-kata tersebut 'didiktekan' melalui suatu saluran yang ada dalam diri nabi, mewujud dalam bentuk "suara yang meratap dari dasar kedalaman hidup nabi, yang berbicara dengan jelas, tidak dapat disangkal dan mendesak". "Dan proses pendiktean tersebut bisa melalui suatu cara yang berdekatan artinya dengan inspirasi.

Menurut Fazlur Rahman sumber inspirasi dan asal dari proses kreatif tersebut terletak di luar capaian biasa agensi (keperantaraan) manusia, namun proses itu timbul dalam suatu pengertian yang pasti sebagai suatu bagian integral dari pikiran Nabi. Artinya, ide-ide dan kata-kata lahir di dalam dan dapat dikembalikan kepada pikiran Nabi, sementara sumbernya dari Allah swt. Dari situ dia menyimpulkan, jika keseluruhan proses timbul dalam pikirannya, maka perkataannya dalam suatu pengertian yang biasa merupakan kata-katanya, sepanjang menyangkut pertimbangan proses psikologis, tetapi perkataan itu juga merupakan kalam Allah swt. yang diwahyukan sepanjang sumbernya terletak diluar capaiannya.

Menurut Fazlur Rahman, bahwa wahyu Al Qur'an lahir dalam hati dan pikiran nabi memang telah ditegaskan sendiri oleh Al Qur'an. Dalam surah al-Syuara : 194, Al Qur'an menegaskan :

${ }^{16}$ Fazlur Rahman, Islam, hlm. 32 
"Ruh yang terpercaya telah menurunkan ke dalam hatimu agar kamu dapat menjadi pemberi peringatan" dan QS.Al-Baqarah : 97 Al Qur' an menegaskan : “ Katakanlah : siapa yang menjadi musuh Jibril (biarkanlah ia begitu) karena dialah yang menurunkannya ke dalam hatimu(dengan seizin Allah)"."17

Fazlur Rahman menegaskan bahwa yang dimaksud dengan Jibril (al-Ruh al Amin) pembawa wahyu bukanlah malaikat yang merupakan agen tersendiri yang berada diluar diri nabi. Menurutnya, yang dimaksud dengan ruh itu adalah kekuatan, kemampuan atau agensi yang berkembang dalam hati Muhammad dan ketika diperlukan dapat berubah menjadi operasi wahyu yang aktual, tetapi pada awal mulanya ruh itu 'turun' dari atas.

Menurut Fazlur Rahman, al-Qur'an merupakan kalam Allah swt. yang mengalir melalui ingatan dan pikiran Nabi Muhammad, sebagai respon Ilahi terhadap situasi sosio-historis masyarakat Arab waktu itu. Dalam keseluruhannya, al-Qur'an menurut Fazlur Rahman merupakan keseluruhan nilai yang bersifat universal. Secara eskatologis al-Qur'an dalam keseluruhannya adalah Firman Allah swt. sekaligus dalam arti kata biasa sebagai perkataan Muhammad. Oleh karenanya dalam pendangan Fazlur Rahman, al-Qur' an dalam hal-hal tertentu mesti dipahami dengan latar belakang historis ketika ia diturunkan supaya benar-benar ditemukan nilai normatif dan moralnya. Karena pada dasarnya semangat dasar al-Qur'an adalah semangat moral yang menekankan monoteisme dan keadilan sosial. ${ }^{18}$

Dalam hubungan dengan situasi sosial tersebut, Rahman menegaskan bahwa al-Qur'an “.......it's literally God's response through Muhammad's mind....to a historic situation. Maksudnya bahwa al-Qur'an adalah respon Tuhan melalui fikiran Muhammad untuk situasi bersejarah. Pada bagian lain ia menyatakan bahwa al-Qur' an "..... a docment that grew within a background from the flesh and blood of actual history; it is therefore both as 'sraight forward' and as organically coherent as life itself', '19 Yang

${ }^{17}$ Fazlur Rahman, Divine Revealation and the Prophet, Vol. I, (T.t.p, T.p , 1978), hlm. 69-70

${ }^{18}$ Fazlur Rahman, Mayor Themes of the Qur'an, hlm. 81

19 Fazlur Rahman, Islam and Modernity: Transformation of an Intelectual Tradition, hlm. 117 
diartikan bahwa al-Qur'an adalah sebuah dokumen yang tumbuh di dalam latar belakang dari daging dan darah sejarah aktual, oleh karena itu keduanya lurus ke depan dan secara organik koheren seperti kehidupan itu sendiri.

Kedua pernyataan tersebut memberikan petunjuk bahwa al-Qur'an tidak bisa dilepaskan begitu saja dari situasi objektif ketika al-Qur'an diturunkan yakni kondisi sosial, ekonomi, politik, religius, dan kualitas kependidikan masyarakat Arab. Aspek itu penting diketahui dalam memahami al-Qur'an secara utuh. Pemahaman ini didasarkan kepada perlunya menafsir ulang tradisi-tradisi yang bersifat historis murni.

Walaupun Rahman berpendapat bahwa al-Qur'an berhubungan erat dengan latar historisnya sendiri, Ia tetap menolak pemahaman bahwa al-Qur' an secara literal hanya berlaku untuk masanya saja. Karena pada dasarnya aspek esensial dari alQur'an menurut Rahman, seperti yang telah diungkapkan di atas, adalah keadilan, sosial, ekonomi, persamaan esensial manusia dengan sinaran tauhid.

\section{E. Kontekstualisasi Al-Qur'an: Tawaran Hermeneutika Double Movements}

Hermeneutika al-Qur'an (tafsiran terhadap wahyu) dan sejarah (konteks Sosial) merupakan usulan yang ditawarkan Fazlur Rahman dalam menafsirkan al-Qur'an. Metode ataupun strategi ini juga merupakan pelindung dan pedangnya. Di satu sisi metode itu menunjukkan bagaimana wahyu telah membuka sejarah. Di sisi lain, ia akan menggunakan al-Qur'an sebagai standar normatif untuk meniadakan tradisi-tradisi lokal juga nilainilai praktik agama yang mengganggu norma-norma yang diperoleh dari al-Qur'an dan sunnah. Menurutnya praktik-praktik yang tidak memajukan visi masyarakat Islam menjadi penghambat kemajuan manusia. ${ }^{20}$ Oleh sebab itulah, tawaran hermeneutika Fazlur Rahman ini perlu dieksplorasi lebih mendalam, khususnya untuk mengetahui bagaimana

${ }^{20}$ Fazlur Rahman, Gelombang Perubahan dalam Islam Studi Tentang Fundamentalisme Islam, Cet. Ke-2, (Jakarta: Raja Grafindo Persada, 2001), hlm. 2 
kontekstualisasi dari hasil pembacaan hermeneutikanya terhadap al-Qur'an bekerja dan mampu diimplementasikan dalam masyarakat kontemporer.

Hermeneutika kesentralan al-Qur'an Fazlur Rahman didasari pada dua pilar, pertama: teori kenabian dan hakikat wahyu, dan kedua: pemahaman sejarah. Kedua komponen itu merupakan hermeneutika umum Fazlur Rahman terhadap alQur'an. Bagi pemikir-pemikir modern seperti Fazlur Rahman sangat penting mengartikan wahyu dalam term (istilah) sejarah. Jika sejarah berpengaruh dalam memahami wahyu yang transenden, maka penting untuk menyelidiki keberadaan wahyu dengan dunia. Dengan kata lain Fazlur Rahman berusaha memberikan teori wahyu yang kompleks, universal, yang menghubungkan alasan-alasan filosofis dan psikologis dengan sejarah sosiologi dan antropologi. Gagasan wahyu yang kompleks ini menjadi latar belakang dari teori penafsiran al-Qur'annya, yang disebut dengan teori double movements (pergerakan ganda). ${ }^{21}$

Pergerakan pertama double movements ini ialah mempelajari konteks sosial - moral dari umat Nabi. Investigasi sejarah tersebut kemudian harus menghasilkan narasi al-Qur'an yang koheren terhadap prinsip-prinsip dan nilai-nilai yang umum dan sistematis serta mampu mendasari perintah-perintah normative yang bermacam-macam. Di sini konsep-konsep dari sebab turunnya wahyu (asbabun nuzul) dan nasakh (penghapusan), disamping teknik-teknik penafsiran lain yang telah diketahui, membuahkan hasil.

Pergerakan kedua yaitu mencoba menggunakan nilai-nilai dan prinsip-prinsip yang umum dan sistematis itu ke dalam konteks pembaca al-Qur'an kontemporer, yakni penerapan nilainilai historis yang didapatkan kembali saat ini memerlukan analisa yang sangat cermat. $^{22}$

Harus disadari bahwa al-Qur'an muncul dalam horizon sejarah dan berhadapan dengan latar belakang sosio-historis, maka menurut Rahman, pendekatan yang paling tepat untuk memahami

${ }^{21}$ Fazlur Rahman, Islam and Modernity, (Bandung: Penerbit Pustaka, 1985), hlm. 8

${ }^{22}$ Fazlur Rahman, Gelombang Perubahan dalam Islam, hlm. 14 
al-Qur'an adalah pendekatan kesejarahan (historical Approach) yaitu suatu pendekatan terhadap al-Qur'an dengan memahami situasi kesejarahan, baik sebelum maupun di masa pewahyuan, untuk kemudian menarik ideal-moral dari wahyu tersebut, dan memproyeksikannya dalam konteks kekinian. Dalam hal ini Fazlur Rahman berharap:

"Saya hanya dapat memohon agar mereka sudi mempelajari masalah penting ini dengan sikap yang objektif dan dengan kejujuran terhadap sejarah. Saya sendiri sebagai seorang Muslim yakin bahwa baik Islam maupun kaum Muslimin tidak akan merugi karena meninjau fakta-fakta sejarah sebagaimana yang sebenarnya, bahkan sebaliknya seperti kebenarankebenaran yang lain kebenaran sejarah akan menguatkan Islam".23

Karena itu Fazlur Rahman memandang pentingnya memahami kondisi aktual masyarakat Arab Pra-Islam dan masa Nabi dalam rangka menafsirkan pernyataan-pernyataan legal dan sosio-ekonomik al-Qur'an. Pendekatan historis ini dipandangnya sebagai satu-satunya cara yang dapat diterima dan dapat berlaku adil kepada tuntutan intelektual ataupun integritas moral. Sebagaimana yang ia ungkapkan: "Hanya dengan cara inilah suatu apresieasi sejati terhadap tujuan-tujuan (cita-cita) moral al-Qur' an dan sunnah dapat dicapai". ${ }^{24}$

Langkah operasional penafsiran kontekstual menekankan pentingnya perbedaan antara ideal-moral dengan ketentuan legal spesifiknya. Seperti dikatakan Fazlur Rahman, bertalian erat dengan perumusan pandangan dunia (weltanschauung) al-Qur'an. Pandangan dunia ini pada gilirannya merupakan basis dirumuskannya etika al-Qur'an, suatu landasan filosofis bagi produk-produk pemikiran Fazlur Rahman, terutama penafsiran kontekstualnya.

${ }^{23}$ Fazlur Rahman, Islamic Methodology in history, (Bandung: penerbit pustaka, 1995), hlm. 23

${ }^{24}$ Fazlur Rahman, Metode dan Aternatif Neomodernisme Islam, hlm. 189 
Dengan dua langkah tersebut Rahman berharap dapat menghasilkan penafsiran yang objektif, atau setidaknya mengurangi subjektifitas penafsir. Hanya saja, hingga akhir 1970 rumusan pendekatan tafsir yang dikemukakan oleh Rahman belum definitif dan masih banyak mengandung kelemahan. Betul bahwa Rahman sejak lama telah menekankan pentingnya memahami alQur'an dengan memahami kesejarahannya, namun dalam tafsir kontekstualnya tersebut Rahman belum secara sempurna membangun gerakan ganda yang menjadi ciri khas pendekatan tafsir yang ditawarkannya. Kekurangsempurnaan gerakan ganda dalam rumusan tersebut nampak pada belum dimasukkannya pertimbangan tentang perlunya memproyeksikan tujuan (idealmoral) al-Qur'an yang disarikan melalui pendekatan kesejarahannya pada konteks kekinian. Sehingga bisa dikatakan bahwa rumusan pendekatan tafsir yang ditawarkan Fazlur Rahman hingga akhir 1970-an belum memiliki signifikansi nyata sehubungan dengan penerapan ideal-moral tersebut dalam situasi konkrit di era kekinian.

Kekurangan yang ada dalam rumusannya di tahun 1970-an tersebut disempurnakan dalam rumusan kedua yang ditulis pada 1979-an. Rumusan yang ditulis dalam artikel yang berjudul "Towords Reformulating the Methodology of Islamic law" tersebut menyertakan pertimbangan perlunya memproyeksikan ideal-ideal moral al-Qur'an dalam konteks kekinian. ${ }^{25}$

Dalam karya monumentalnya yang berjudul Islam Modernity, Rahman mengatakan bahwa yang pertama dari gerakan ganda (double movement) tersebut terdiri dari dua langkah. Pertama mufassir harus memahami arti atau makna suatu pernyataan tertentu dengan mempelajari situasi atau problem historis di mana pernyataan tersebut merupakan jawabannya, dengan terlebih dahulu mengkaji situasi makro dalam batasanbatasan masyarakat, agama, adat-istiadat, pranata-pranata, bahkan tentang kehidupan secara menyeluruh dikawasan Arab pada saat masuknya Islam, yang bertujuan untuk memahami alQur'an secara utuh dalam batasan-batasan ajaran spesifik yang merupakan respon atas situasi-situasi spesifik.

${ }^{25}$ Fazlur Rahman, Metode dan Aternatif Neomodernisme Islam, hlm. 
Kedua, menggeneralisasikan jawaban-jawaban spesifik tersebut dan menyatakannya sebagai pernyataan-pernyataan yang memiliki tujuan sosio-moral umum yang dapat disarikan dari teks-teks spesifik al-Qur'an dalam sinaran latar -belakang sosiohistoris dan rasio-legis yang dinyatakan. Mufassir harus mengarahkan perhatiannya pada tujuan al-Qur'an (ideal-moral) sebagai suatu keseluruhan yang utuh, sehingga akan memunculkan suatu sikap yang pasti terhadap kehidupan dan memiliki suatu pandangan dunia (weltanschaung) yang konkret. ${ }^{26}$

Dengan memahami pandangan dunia (weltanschaung) tersebut, diharapkan akan dihasilkan suatu rumusan etika alQur'an yang pada gilirannya akan mewarnai produk-produk penafsiran kontekstual. Penafsiran yang ditawarkan Rahman mempunyai kaitan organis dengan pandangan dunia (weltanschauung) dan etika al-Qur'an. Batasan yang digariskan oleh Fazlur Rahman memang tegas sekali. Tolak ukur yang dipakai oleh Rahman dalam menilai dapat tidaknya pandangan dunia al-Qur'an itu dipergunakan sangat jelas. Rumusan pandangan dunia yang harus memenuhi dua fungsi sekaligus, fungsi intelektual dan fungsi spiritual. Ketika rumusan pandangan dunia yang dipakai tidak dapat memenuhi salah satu dari dua fungsi tersebut maka sudah semestinya ditinggalkan.

Sedangkan etika al-Qur'an, suatu bangunan kerangka pikir yang berbasiskan pandangan dunia al-Qur'an, merupakan esensi ajaran kitab suci dan merupakan mata rantai yang menghubungkan antara pandangan dunia al-Qur'an dengan penafsiran al-Qur'an. Etika al-Qur'an menurut Rahman, di bangun di atas pedoman tiga istilah kunci, yakni iman, Islam dan taqwa. Ketiga istilah tersebut, menurut Rahman, memiliki pengertian yang mirip. Istilah pertama berasal dari akar kata $a-m-n$ yang berarti aman, bebas dari bahaya, dan damai. Istilah kedua berasal dari akar kata $s-1-m$ yang berarti aman, integral, terlindung dari disintegrasi dan kehancuran. Sedangkan istilah yang terakhir berasal dari akar kata $w-q-y$ yang berarti melindungi dari bahaya, menjaga kemusnahan, tersia-siakan atau disintegrasi. ${ }^{27}$

${ }^{26}$ Fazlur Rahman, Metode dan Aternatif Neomodernisme Islam, hlm.

${ }^{27}$ Fuzlur Rahman, Interpreting the Qur'an, hlm. 66 
Menurut Rahman, secara langsung etika al-Qur'an mangarahkan kita untuk melindungi dan mengembangkan integritas para individu dan kolektif. Apa saja yang akan kondusif bagi integritas tersebut akan menjadi baik, apa saja yang menghalangi integritas dan membawa kearah disintegrasi serta kemusnahan akan menjadi jelek. Tafsir kontekstual, oleh pencetusnya yang memang sangat akrab dengan pemikiranpemikiran filsafat, ditampilkan dengan refleksi filosofis. Sehingga tafsir kontekstual tidak mengemuka begitu saja tanpa adanya basis pemikiran yang kuat, melainkan memiliki akar pemikiran yang menancap dalam.

\section{F. Contoh Produk Penafsiran Fazlur Rahman}

Untuk mendapatkan gambaran lebih utuh mengenai pemikiran tafsir kontekstual yang ditawarkan Rahman, ada baiknya dikemukakan contoh produk penafsiran yang dikemukakannya dalam beberapa karyanya. Dalam hal ini tidak akan dikemukakan keseluruhan produk penafsiran yang dikemukakan Rahman, melainkan hanya beberapa saja, diantaranya:

\section{Tentang Pengharaman AlKohol (Khamr)}

Kaitannya dengan pengharaman khamr, Rahman mengatakan bahwa pada periode Makkah, dalam surat an-Nahl, al-Qur'an menyebutnya sebagai salah satu rahmat Tuhan bersama-sama denga susu dan madu (QS. Al-Nahl: 66-69). Ketika kaum muslimin hijrah ke Madinah, ada kabar bahwa ada sekelompok orang- Umar bin Khattab ada di antara mereka- yang menginginkan agar al-Qur'an mengumumkan pelarangan alkohol (khamr). Dalam QS. Al-Baqarah: 219, dinyatakan bahwa:

"Orang-orang ini tetap bertanya tentang alkohol dan permainan undian, katakanlah kepada mereka bahwa terdapat kejahatan besar dalam keduanya, tetapi juga ada manfaat-manfaat tertentu didalam keduanya. Namun kejahatan (dosa) nya lebih besar daripada manfaatnya".

Setelah beberapa waktu, ada pesta yang diselenggarakan di rumah salah seorang sahabat Anshar, di mana beberapa orang muslim minum alkohol dan karenanya ia mabuk. Ketika salah seorang di 
antaranya mengimami shalat malam, ia keliru dalam membaca alQur'an. Ketika peristiwa ini dilaporkan kepada Nabi, maka turunlah QS. Al-Nisa: 43, yang menyatakan:

"janganlah dekati shalat ketika kamu mabuk (berada dibawah pengaruh alkohol), sehingga kamu mengerti apa yang kamu ucapkan”.

Kemudian, pada suatu hari diadakan pesta lagi, mereka banyak minum khamr, sehingga terjadi pertengkaran dengan mengutip syair-syair Arab pra Islam untuk memojokkan suku-suku lainnya dan terjadilah baku hantam di antara mereka, ketika peristiwa itu dilaporkan kepada Nabi, maka turunlah surat al-Maidah: 90-91, yang menyatakan:

'hai orang-orang yang beriman, sesungguhnya (meminum) khamr, berjudi,(berkorban untuk) berhala, mengundi nasib dengan anak panah adalah termasuk perbuatan syaitan, maka jauhilah perbuatan itu agar kamu mendapat keberuntungan". "Sesungguhnya syaitan itu bermaksud hendak menimbulkan permusuhan dan kebencian di antara kamu lantaran (meminum) khamr dan berjudi itu, dan menghalangi kamu dari mengingat Allah dan shalat, maka berhentilah kamu (dari mengerjakan pekerjaan itu)".

Kesimpulan apa yang dapat kita tarik dari peristiwa tersebut?. Tentang pengharaman khamr ini, para fuqaha' mengatakan bahwa ayat khamr yang terakhir (QS. Al-Maidah: 9091) yang harus dipegang, sementara ayat-ayat sebelumnya terhapus (mansukh). Mereka menyeru kepada doktrin naskh, yakni penghapusan aturan-aturan hukum tertentu oleh aturan-aturan lainya. Tetapi kasus ini tidak bisa diselesaikan hanya dengan suatu seruan kepada prinsip naskh. Oleh karena itu, para fuqaha' merasionalisasikan penerapan prinsip naskh dalam kasus ini dengan menyeru kepada prinsip lainnya yang disebut hukum graduasi, yang berarti bahwa setidak-tidaknya dalam kasus tertentu, al-Qur'an dalam rangka menghentikan kaum muslimin dari adat-istiadat yang sudah berkembang luas dikalangan mereka sebelum Islam mempergunakan prinsip graduasi ketimbang penghapusan (naskh) seketika sebagai suatu prinsip. Jika kasus ini dapat diselesaikan hanya dengan prinsip graduasi atau naskh, maka al-Qur'an tidak memulainya dengan memuji khamr dan memasukkannya sebagai di antara rahmat Allah swt. dengan 
kemudian mengumumkannya sebagai pekerjaan syaitan. Oleh karena itu, hukum graduasi ini mutlak di topang oleh pertimbangan-pertimbangan lainnya untuk membuat kontradiksi ini dapat dipahami.

Ketika Nabi masih berada di Makkah, kaum muslimin merupakan komunitas informal yang sangat kecil. Mereka masih belum merupakan suatu masyarakat (society). Tampak bahwa sebagian besar dari mereka tidak mengkonsumsi khamr pada waktu itu. Belakangan ketika orang-orang Makkah terkemuka seperti Hamzah dan Umar bin Khatthab masuk Islam sekitar tahun $614 \mathrm{M}$, masih ada beberapa orang di antara mereka yang minum khamr. Tetapi fenomena ini tidak menimbulkan apapun kepada kaum muslimin, sebab mereka belum merupakan suatu masyarakat (society), melainkan hanya komunitas informal. Namun ketika kaum muslimin hijrah ke Madinah, mereka tidak hanya menjadi masyarakat, tetapi juga semacam Negara informal. Minum khamr pada waktu itu berkembang menjadi suatu masalah baru. Seseorang bisa saja mengatakan bahwa pengetatan alQur'an terhadap konsumsi khamr ketimbang melarangnya dengan segera dalam dua ayat Madaniyah yang awal (QS. al-Baqarah: 219 dan al-Nisa': 43) tentang masalah tersebut merupakan pelaksanaan hukum graduasi ketimbang pelarangan khamr seketika dan secara total yang dilakukan sebagai upaya terakhir. ${ }^{28}$

\section{Tentang Poligami}

Fazlur Rahman juga memberikan penjelasan tentang poligami yang oleh para fuqaha' di anggap sebagai asas perkawinan yang sah menurut Islam.

Al-Qur' an surat al-Nisa: 3 mengatakan:

"(isterimu), jika kamu takut tidak dapat berlaku adil kepada anakanak yatim, maka kawinilah dua, tiga atau empat orang di antara mereka. Tetapi jika kamu takut tidak dapat berlaku adil (terhadap isteri-maka kawinilah satu orang saja)".

Dalam surat Ali Imran: 2, al-Qur'an mengutuk para wali dari anak-anak yatim laki-laki dan perempuan, karena menyelewengkan harta kekayaan mereka, padahal ayat ini telah diturunkan di Makkah (QS. Al-An'am: 152 dan al-Isra': 34) dan

${ }^{28}$ Fazlur Rahman, Interpreting the Qur'an, hlm. 59-61 
kemudian lebih ditekankan di Madinah (QS. al-Baqarah: 220 dan al-Nisa': 2, 6, 10 dan 127). Lalu al-Qur' an menyatakan agar tidak menyelewengkan harta anak yatim, para wali tersebut boleh mengawini sampai empat orang diantara mereka, dengan syarat mereka (para wali) dapat berbuat adil. Kebenaran penafsiran ini, menurut Fazlur Rahman, di dukung oleh surat an-Nisa': 127, yang mungkin saja lebih dulu diturunkan daripada surat al-Nisa: 3 .

Al-Qur' an surat al-Nisa': 127 menyatakan bahwa:

"mereka bertanya kepadamu (Muhammad): mengenai kaum perempuan. Katakanlah bahwa mengenai mereka itu Allah memberikan keputusan-Nya, yang dibacakan kepadamu dalam kitab ini mengenai perempuan yatim yang tidak dapat kamu penuhi hak mereka, tetapi lebih suka kamu kawini, dan (juga mengenai) anak-anak yang (lebih muda dan lemah)".

Keterangan ini menunjukan bahwa masalah ini timbul dalam konteks perempuan-perempuan yatim, tetapi al-Qur'an juga menyatakan dalam surat al-Nisa ayat 129:

"Betapapun kamu mengingikannya, namun kamu tidak akan dapat berlaku adil terhadap perempuan-perempuan tersebut". ${ }^{29}$

Bagi Fazlur Rahman, dalam permasalahan poligami ini, persyaratan berlaku adil ini harus mendapat perhatian dan ditetapkan sebagai kepentingan mendasar ketimbang persyaratan spesifik yang memperbolehkan poligami. Tuntutan untuk berlaku adil dan wajar merupakan salah satu tuntutan dasar keseluruhan ajaran al-Qur'an.

Dalam hal ini, Fazlur Rahman menegaskan bahwa pernikahan monogami merupakan sebuah pernikahan yang sangat ideal guna meraih kebahagian dalam rumah tangga sebagaimana yang dikehendaki Allah swt. dalam firman-Nya tersebut. Tetapi tujuan moral ini harus berkompromi dengan kondisi aktual masyarakat Arab pada abad $7 \mathrm{M}$, yang asas poligami berakar kuat pada masyarakat, sehingga secara moral tidak dapat dicabut secara seketika karena akan menghancurkan tujuan moral itu sendiri.

Bagi Rahman suatu hal yang sangat bertentangan sekali, kaum laki-laki dituntut berlaku adil kepada istri dalam pernikahan

${ }^{29}$ Fazlur Rahman, Mayor Themes of the Qur'an, hlm. 47-48 
yang dijalininya, sementara satu sisi diperkenankan untuk berpoligami sampai berjumlah empat. Menurut penafsiran klasik, izin berpoligami mempunyai kekuatan hukum, sedangkan berbuat adil kepada istri hanya terserah kebaikan suami. Dari sudut pandang agama yang normatif, keadilan terhadap istri yang memiliki posisi lemah tersebut, hanya bergantung kepada kebaikan suami, walaupun pasti akan dilanggar. Sebaliknya, para modernis muslim cenderung untuk mengutamakan keharusan untuk berbuat baik serta adil dan pernyataan al-Qur'an bahwa izin untuk berpoligami itu hanya untuk sementara waktu dan tujuantujuan tertentu saja. ${ }^{30}$

Demikianlah, contoh penafsiran yang dikemukakan Fazlur Rahman dalam mengakses ayat-ayat al-Qur'an dan kaitannya dengan konteks kekinian. Ia tampak berusaha mengimplementasikan ideal moral ayat-ayat tersebut dalam konteks masyarakat kontemporer dengan mengedapankan konteks kesejarahan yang melingkupi teks-teks tersebut.

\section{G. Kesimpulan}

Penafsiran kontekstual (teori double movements) yang ditawarkan Fazlur Rahman merupakan konsekuensi logis dari pandangannya tentang al-Qur'an. Fazlur Rahman berkesimpulan bahwa al-Qur'an adalah respon Ilahy melalui hati atau pikiran Nabi. Karenanya, al-Qur'an dalam pengertian bahwa ia merupakan respon Ilahy dan muncul di luar capaian Nabi Muhammad saw adalah kalam Allah, dan dalam pengertian bahwa ia lahir melalui pikiran atau hati Nabi juga merupakan perkataan Nabi Muhammad. Al-Qur'an muncul dalam sinaran sejarah dan berhadapan dengan latar belakang sosio-historis, karenanya, pendekatan yang paling tepat untuk memahaminya adalah pendekatan kontekstual atau pendekatan kesejarahan (historical approach). Oleh sebab itulah ia menawarkan metode pembacaan double movements.

Teori double movements merupakan suatu upaya untuk mendekati al-Qur'an dengan memahami situasi kesejarahan baik sebelum maupun di saat pewahyuan untuk menarik ideal- moral

\footnotetext{
${ }^{30}$ Fazlur Rahman, Mayor Themes of the Qur'an, hlm. 48
} 
atau maksud yang hendak dicapai al-Qur'an tersebut untuk kemudian memproyeksikannya dalam konteks kekinian. Dalam memproyeksikan ideal moral terhadap konteks kekinian, mufassir harus mengarahkan perhatianya pada tujuan al-Qur'an (idealmoral) sebagai suatu keseluruhan yang utuh, sehingga akan memunculkan suatu sikap yang pasti terhadap kehidupan dan memiliki suatu pandangan dunia (weltanschaung) yang konkret. Karena dengan memahami pandangan dunia (weltanschaung) tersebut akan dihasilkan suatu rumusan etika al-Qur'an. Tolak ukur yang dipakai oleh Rahman dalam menilai mampu tidaknya pandangan dunia al-Qur'an itu dipergunakan sangat jelas. Rumusan pandangan dunia harus memenuhi dua fungsi sekaligus, fungsi intelektual dan fungsi spiritual. Ketika rumusan pandangan dunia yang dipakai tidak dapat memenuhi salah satu dari dua fungsi tersebut maka sudah semestinya ditinggalkan.

Etika al-Qur'an menurut Rahman, di bangun di atas pedoman tiga istilah kunci, yakni Iman, Islam dan Taqwa. Ketiga istilah tersebut, menurut Rahman, memiliki pengertian yang mirip. Istilah pertama berasal dari akar kata $a-m-n$ yang berarti aman, bebas dari bahaya, dan damai. Istilah kedua berasal dari akar kata $s$-1-m yang berarti aman, integral, terlindung dari disintegrasi dan kehancuran. Sedangkan istilah yang terakhir berasal dari akar kata $w-q-y$ yang berarti melindungi dari bahaya, menjaga kemusnahan, tersia-siakan atau disintegrasi. Menurut Rahman, secara langsung etika al-Qur'an mangarahkan kita untuk melindungi dan mengembangkan integritas para individu dan kolektif. 


\section{DAFTAR PUSTAKA}

Abi al-Hasyan Ahmad Ibn Faris ibn Zakariya, Maqayis al-lughah, juz IV, Mesir: Mustafa al-Babi al-Halai, 1970

Ahmad al-Syirbasyi, Sejarah Tafsir al Qur'an, terj. Tim Pustaka Firdaus, T,t,p: Pustaka Firdaus, 1994

Akhmad Arif Junaidi, Pembaruan Metodologi Tafsir Al Qur'an, Semarang: Gunung Jati, 2000, cet, ke-1

Ahmad Syafi'i Ma'arif, Fazlur Rahman, Al Qur'an dan Pemikiran Islam, kata pengantar dalam terjemahan Ahsin Muhammad untuk karya Rahman, Bandung: Pustaka Islam, 1984

Departemen Agama RI, Al-Qur'an dan Terjemahannya, Jakarta: Syamil cipta Media, 2005,

Fazlur Rahman, An Autobiographical Note, terjemahan. Ihsan Ali Fauzi, Yogyakarta: Al-Hikmah Volume. VI, Juli-Oktober, 1992

, Divine Revealation and the Prophet, Vol.I, 1978

Gelombang Perubahan Dalam Islam Studi

Tentang Fundamentalisme Islam, Jakarta: Raja Grafindo Persada, 2001, Cet. ke-2

1986)

, Interpreting the Qur'an, dalam (inquiry, Mei, Islam, Bandung: Pustaka, 1994, Cet. ke-2

, Islam and Modernity. Transformation of an Intelectual Tradition, Chicago: The University of Chicago Press, 1982

Pustaka, 1985

Islam and Modernity, Bandung: Penerbit , Islamic Methodology in History, Bandung:

Penerbit Pustaka, 1995 Bibliotheca Islamica, 1980), N.K. Singh dan A.R. Aqwan(ed), Ensyclopedia of The Holy Qur'an, vol. 1, Delhi: Global Vision Publishing House, 2000, cet. 1 
--or The Qur'an, Chicago: Bibliotheca Islamica, 1980 , Metode dan Aternatif Neomodernisme Islam, Terjemahan Taufiq Adnan Amal, Bandung: Mizan, 1987

Hasbi Ash-Shiddiqie, Ilmu-ilmu al-Qur'an: Ilmu-ilmu pokok Dalam Menafsirkan Al-Qur'an, Semarang: Pustaka Rizki Putra, 2002

M. Dahlan. Y. Al-Barry, L.Lya Sofyan Yacub, Kamus Induk Istilah Ilmiah Seri Intelektual, Surabaya: Target Press, 2003

Metcalf, Barbara Daly, Islamic Revival in British India: Doeband, 1860-1900, Princeton: Princeton University Press, 1982

Umar Shihab, Kontekstualitas Al-Qur'an Kajian Tematik atas Ayat-ayat Hukum Dalam Al-Qur'an, Jakarta: Pena Madani, 2005 